\title{
Assessing the ecological value of dynamic mountain geomorphosites
}

\author{
Jonathan Bussard ${ }^{1}$ and Elisa Giaccone ${ }^{2}$ \\ ${ }^{1}$ Institute of Geography and Sustainability and Interdisciplinary Centre for Mountain Research, \\ University of Lausanne, Sion, Switzerland \\ ${ }^{2}$ Institute of Earth Surface Dynamics, University of Lausanne, Lausanne, Switzerland
}

Correspondence: Jonathan Bussard (jonathan.bussard@unil.ch)

\begin{abstract}
Received: 25 February 2021 - Revised: 13 September 2021 - Accepted: 15 September 2021 - Published: 4 October 2021
Abstract. Geoheritage is a component of geodiversity constituted by all the elements of geodiversity recognized by society for their particular values. The definition of these values, including the importance of geoheritage for biodiversity, plays a key role in the process of heritage recognition and geoconservation policymaking. In mountain environments, dynamic geomorphosites have a strong influence on plant diversity because the active geomorphological processes responsible for their formation act as renovators for habitats of pioneer species. In this paper, we propose criteria to assess the ecological value of dynamic mountain geomorphosites. We show that the interest of plant communities (species richness and presence of rare or protected species) and the influence of geomorphological processes on plant communities (disturbances, surface movement and soil) are fundamental criteria for assessing the ecological value in an exhaustive and objective way and that the question of the scale (local and national scales) is also a crucial parameter. We then illustrate this methodological proposal by evaluating the ecological value of three dynamic geomorphosites and a talus slope in the western Swiss Alps.
\end{abstract}

1

\section{Introduction}

The close relationships between geomorphology and biodiversity are not sufficiently taken into account in the field of geomorphosite characterization, assessment and conservation (Pelfini et al., 2010; Bollati et al., 2015; Reynard et al., 2016; Bétard, 2017). There is indeed particularly little discussion in the literature about the assessment of the ecological value of geomorphosites (Reynard and Panizza, 2005; Reynard, 2009). A literature review presented in this paper shows that in most of the current methods, the criteria used to assess the ecological value are not defined with sufficient precision in view of the many interrelationships existing between geomorphology and biological features and the positive impacts that certain geomorphosites can have on biodiversity. The aim of this article is to clarify and objectivize the assessment of the ecological value of dynamic mountain geomorphosites. A complete evaluation of the ecological value should take into account the impacts of geomorphological processes and landforms on vegetation diversity and on fauna diversity. In this article, we propose to look further into the question of the impact of dynamic mountain geomorphosites on vegetation diversity. We first give a general overview of the issue according to the existing literature and then suggest the definition of criteria that should be used for a more accurate and objective assessment of the ecological value of this category of geomorphosites. We finally apply these criteria for the assessment of the ecological value of three mountain geomorphosites (i.e. landforms with a high scientific value) - a rock glacier, a pre-Little Ice Age (LIA) moraine complex and a lateral moraine from the LIA - and of a talus slope located in the Vallon de Nant (western Swiss Alps).

\section{State of the art}

\subsection{Geodiversity, biodiversity, geoheritage and their relationships}

Geodiversity is "the natural range (diversity) of geological (rocks, minerals, fossils), geomorphological (landforms, topography, physical processes), soil and hydrological fea- 
tures" (Gray, 2013:12). Geodiversity is the abiotic equivalent of biodiversity and therefore is a value-neutral term (Gray, 2018), except for the existence value of everything that constitutes geodiversity (Brilha, 2018). However, some specific elements of geodiversity have particular values from an anthropogenic point of view, especially when they provide abiotic ecosystem services, also called geosystem services (Gray, 2011). It is important to mention that ecosystem services not only are ecological (biotic) but can also be provided by geodiversity and that the benefits obtained from geodiversity can be of two types: direct (e.g. the beauty of an alpine landscape) or indirect, through the influence that geodiversity and related forms and processes have on biodiversity (Gordon and Barron, 2011). Geoheritage is a component of geodiversity (Gray, 2018), constituted by all the elements of geodiversity recognized by society for their particular values. The societal process by which a geological asset (element of geodiversity) becomes heritage is based on the values attributed to heritage by the different societal stakeholders over time (Portal, 2010; Reynard et al., 2011; Martin, 2013). The definition of geoheritage values, including its importance for biodiversity, therefore plays a key role in the process of heritage recognition and geoconservation policymaking (Reynard and Panizza, 2005). Geomorphological heritage is a part of geoheritage, and geomorphosites are the specific elements constituting it. Compared to other categories of geosites, geomorphosites are formed by active geomorphological processes that have a strong influence on biodiversity. The dynamic dimension is a specific characteristic of geomorphosites that distinguishes them from other types of geosites (Reynard, 2004a, 2009; Reynard and Coratza, 2013; Coratza and Hobléa, 2018).

In the field of nature conservation, many authors note that geodiversity and geoheritage do not receive sufficient institutional recognition, while biodiversity receives much attention (e.g. Brilha, 2002; Sharples, 2002; Gray, 2004, 2005; Pralong, 2006; Larwood et al., 2013; Gray et al., 2013; Crofts, 2014, 2018; Brilha et al., 2018; Gordon et al., 2018a, b). In Switzerland (Reynard et al., 2005, 2021; Strasser et al., 1995) and in Italy (Giovagnoli, 2017) for example, the protection of geosites and geomorphosites is mainly indirect, for their ecological or landscape characteristics, and not for their own geoscientific value. Swiss legislation emphasizes the protection of biotopes and landscapes of national importance through various inventories (described in the Federal Act on the Protection of Nature and Cultural Heritage) that often include geosites and geomorphosites, even if they are not specifically targeted. We must also mention that some countries, on the contrary, have integrated direct references to geoheritage within their legal framework, for instance the UK (Prosser, 2008), Spain (Carcavilla et al., 2009) and Norway (Erikstad, 2013), and that the International Union for Conservation of Nature (IUCN) published new guidelines on geoheritage conservation in protected areas in 2020 (Crofts et al., 2020, 2021). In addition to their geoscientific interest, some geosites and geomorphosites also have strong interactions and a positive influence on biodiversity (Hjort et al., 2015; Bétard, 2017). In order to conserve biodiversity in the context of climate change, the importance of protecting the abiotic conditions that support life has indeed been recognized as a fundamental underpinning (Anderson and Ferree, 2010; Beier and Brost, 2010).

The "nature's stage" framework, introduced by Lawler et al. (2015), illustrates how important it is to conserve the "stage" (geodiversity) as well as the "actors" (biodiversity), which are highly interdependent. In addition, we can consider that some geomorphosites not only are a motionless stage but also constitute active and moving scenery with strong interactions with living species (Bollati et al., 2018, 2019). The activity of a geomorphosite, as well as that of a landform in general, results from morphoclimatic factors (exogenous processes), climate being a key factor, and endogenous factors such as the tectonic context and structural features (Pelfini and Bollati, 2014). Active geomorphosites are those currently shaped by the processes responsible for their formation, while inactive geomorphosites are those which are not evolving anymore under the action of these responsible processes. A change in morphoclimatic conditions or in tectonic and structural conditions can lead to a modification in the activity of a geomorphosite. For example, the current warming of temperatures in mountain environments leads to the retreat of glaciers and to the degradation of permafrost, two consequences that impact the activity of glacial and periglacial processes and affect the related geomorphosites. In addition, a distinction must be made between the processes responsible for the genesis of a geomorphosite - for a moraine, sediment transport and deposition by a glacier is the responsible process - and processes affecting the geomorphosite under different conditions - erosion of a moraine ridge by weathering after the glacier retreat, for example. This shows that a geomorphosite can be inherited (or passive with regard to the processes responsible for its genesis) but affected by other active processes. To avoid confusion with active geomorphosites, Pelfini and Bollati (2014:139) suggested calling "evolving passive geomorphosites" the inherited geomorphosites that are affected by other processes. We consider that active geomorphosites and evolving passive geomorphosites are dynamic geomorphosites.

Over the past 30 years, the bidirectional relationship between geomorphology and biological features has been the subject of many publications and has led to the development of the biogeomorphology, defined as the study of interactions between geomorphological processes and structures and living organisms, like plants, animals and microorganisms (Knox, 1972; Gorbushina, 2007). Inside the biogeomorphology, we can distinguish zoogeomorphology (interrelationship between fauna and geomorphology - Butler, 1995), phytogeomorphology (influence of topography on plant communities - Howard and Mitchell, 1985) and dendrogeomorphology (use of tree rings to study geomorphic processes, 
e.g. Pelfini et al., 2010; Bollati et al., 2018, 2019), leading to a much better understanding of the impacts of geodiversity (and especially geomorphology) on biodiversity and vice versa (Viles, 2004, 2019). In addition, the living organisms affect the geomorphological processes at multiple spatial-temporal scales, through many biotic actions such as biostabilization, bioerosion and bioturbation (e.g. Butler, 1995; Phillips and Lorz, 2008; Wilkinson et al., 2009; Corenblit et al., 2011; Rice et al., 2012). In recent years, the scientific community has come to understand that vegetation plays an important role in the influence of the geomorphological processes, especially in helping reduce soil erosion (Zheng, 2006; Osterkamp et al., 2012), and that bidirectional and interconnected relationships exist between these components (Stallins, 2006). Numerous papers have demonstrated the biogeomorphic feedback in many dynamic environments such as rivers (Corenblit et al., 2007), periglacial environments (Hjort and Luoto, 2009), glacier forelands (Moreau et al., 2008) or alluvial fans (Lane et al., 2016). The dynamic geomorphological parameters can therefore have various effects on vegetation distribution and community composition, particularly in mountain environments.

\subsection{Evaluation of the ecological value of geomorphosites in the literature}

The "geoscientific value" (value for geosciences) or the importance of a landform in the understanding of the Earth's history and ongoing geomorphological processes is a determining criterion, from the point of view of geologists and geomorphologists, for the recognition of geomorphosites as a part of the natural heritage that must be protected for future generations (Grandgirard, 1997a). As an example, the first actions of geoconservation in Switzerland were based on the recognition of a high geoscientific value: erratic boulders were the first geomorphosites to be protected in the country, as early as 1838 (Pierre-à-Bot in Neuchâtel), because of their great value for the understanding of glacial and climatic history by the scientific community (Reynard, 2004c). However, the geoscientific interest is not the only heritage value of geomorphosites: other features also deserve heritage recognition, in particular their aesthetic, ecological and cultural values, defined by Reynard $(2005,2009)$ as "additional values". The assessment of geoscientific and additional values of geomorphosites is the subject of a large number of publications and methodological proposals (Brilha, 2018), but there is currently no consensus on the best method to apply, as it depends significantly on the aim of the research. While some of the main criteria for assessing scientific value (rarity, representativeness, integrity) are mentioned in most methods, the criteria for assessing additional values are much more heterogeneous (Mucivuna et al., 2019). If the assessment of the aesthetic value can be considered very subjective, the evaluation of ecological and cultural values is dif- ficult without collaboration with specialists from disciplines other than geosciences (Panizza, 2001; Reynard et al., 2016).

Since the first definition of the concept (Panizza, 2001), it has been recognized that geomorphosites have an ecological value because they support biodiversity and can be exclusive habitats for certain animal or plant species (e.g. Gentizon, 2004; Panizza and Piacente, 2004; Reynard, 2004b; Bollati et al., 2015). In addition, it has been shown that the dynamic dimension of some geomorphosites has a positive impact on biodiversity. For example, alluvial floodplains allow a constant renewal of wetlands of high ecological value through successive floods and alluvial deposits (Reynard et al., 2005; Corenblit et al., 2007; Atkinson et al., 2018). For this reason, alluvial floodplains in Switzerland are recognized as "biotopes of national importance" under the Federal Act on the Protection of Nature and Cultural Heritage, and the conservation measures are aimed in particular at restoring the natural dynamics of the water regime and sediment transport. Other examples of a close relationship between dynamic geomorphology and biodiversity have been studied in coastal environments (Stallins and Corenblit, 2018; Eveillard-Buchoux et al., 2019).

As a result of these observations, several publications have integrated the ecological value of geomorphosite as a complement to the geoscientific value, but few of them have proposed a complete definition or defined specific evaluation criteria. For example, Bruschi and Cendrero (2005), Pelfini and Gobbi (2005), Pereira et al. (2007), and Kubalíková (2013) proposed a quantitative evaluation of the ecological value, with high scores for the sites where "valuable" or "interesting" fauna and/or flora was observed, but without explaining the link with a specific geomorphological landform. Pralong (2005) suggested that the ecological interest depends on the species rarity and diversity (number of different species). These more detailed criteria are welcome for an objective assessment but still do not specify the impact of geomorphology on biodiversity. Reynard et al. (2007) recognized that "the importance of the geomorphosite for the development of a particular ecosystem or the presence of a particular fauna and vegetation" needs to be assessed using the literature or directly with specialists, suggesting an interdisciplinary approach to the issue, but this proposal has not been further developed. In the same way, Bollati et al. (2015) proposed that the "ecologic support role" of geomorphosites should have a low score $(0.33 / 1)$ if there is a "presence of interesting flora and fauna", a high score $(0.67 / 1)$ if "the geomorphological features condition/favour the ecosystems", and a maximum score $(1 / 1)$ if "the geomorphological features determine the ecosystems". The score is zero if the geomorphosite has no connection with the biological element.

Some authors (e.g. Cocean and Cocean, 2017; Reynard et al., 2007; Zouros, 2007; Štrba et al., 2015) have proposed linking ecological value to the protection status of the site, arguing that the decision to classify a site under strict protection, particularly in a protected area of national or inter- 
national importance, proves that the ecological value is high and preserved. This approach presupposes that all sites of high ecological value are inventoried and protected, which is not always the case, or neglects high-value sites located outside protected areas. According to Bétard (2017:42), the evaluation of the ecological value "should systematically refer to a biopatrimonial assessment of the case in question" (our translation), which goes beyond the mere consideration of protection status.

This literature review, although not exhaustive, shows that the assessment of the ecological value is problematic in the vast majority of geomorphosite studies. If the dynamic geomorphological parameters are not sufficiently taken into account in the geomorphosite assessment methods, they are also less considered in species distribution modelling, models that examine the impact of various threats on biodiversity and act as support for political decisions about conservation (Guisan et al., 2013; Mod et al., 2016). It would be necessary, on the one hand, to clarify in which cases the high ecological value of a site (presence of rare species or high biodiversity) is linked to its specific geomorphological characteristics and, on the other hand, to better explain the influence of dynamic geomorphological processes on vegetation renewal. The next section aims to discuss these issues from a biogeomorphological perspective and with a focus on mountain environments and mountain plant species.

\subsection{Impacts of geomorphological processes and landforms on vegetation in mountain environments}

In mountain environments vegetation is influenced by climatic factors, such as intense solar radiation, cold temperatures, low atmospheric pressure, abundant snowfalls and strong winds (Körner, 2003), and topographic factors, for example slope angle, aspect and grain size, which generate multiple microhabitats allowing the existence of a mosaic of plant communities in small areas (Scherrer and Körner, 2011). Soil and water availability are fundamental controlling factors for plant development as well (Buri et al., 2017). Mineral resources and water are acquired by mountain plants from substrates, but they can change in very short distances, giving place to a large variety of soil types. In this panoramic view of climatic, topographic and edaphic processes, which have an impact on the development of plant communities, a significant role is also played by the disturbances related to geomorphic processes and landform types. Disturbances are "environmental fluctuations and destructive events" (Picket and White, 1985), and they have been examined in many studies in Arctic-alpine environments (Gentili et al., 2013; le Roux and Luoto, 2014; Virtanen et al., 2010). Several investigations have demonstrated a key role of the geomorphic processes in modifying the microhabitat conditions; in controlling the community composition, the species distribution and the species richness (number of plant individuals); in increasing the colonization of plant species adapted to the dis- turbance (Corenblit et al., 2011; Gentili et al., 2010); and in influencing the treeline position (Masseroli et al., 2016).

The mountain environments are characterized by various landforms, based on the main geomorphological processes that drive them. In a typical mountain glacial valley, we can observe moraines built by the glacier and rock glaciers driven by creeping processes related to permafrost presence and materials eroded, transported and deposited by water, including debris flows, rockfalls or rockslides due to gravitational and freezing-thawing processes. In all these landforms, the vegetation cover will be different based on the age, frequency and intensity of the process. For example, the plant colonization of a morainic deposit is weak in the first years after the glacier retreat and in the proximity of the glacier front because there is not an adequate substrate for plant life (Matthews, 1992). Only a few species, called pioneer species, can survive in these environments. The time since deglaciation, grain size, soil water content, topography, disturbance and snowmelt drive the initial plant colonization. After some decades, biotic processes are affirmed and allow for a more developed vegetation stage in areas distant from the glacier front with shrubs and trees (Burga et al., 2010; Erschbamer et al., 2008; Garavaglia et al., 2010). In this case, we note, on the one hand, that the active geomorphological processes allow the existence of very diversified vegetation whose composition and development depend on the period of glacier retreat and, on the other hand, that the degree of vegetation cover and its richness help in dating a glacial retreat (Burga et al., 2010). Equally, the plant diversity on rock glaciers can be adopted to distinguish an active, inactive and relict rock glacier. Several authors have demonstrated that surface disturbances and micro-topography produced by permafrost creep are important environmental factors that control plant growth. Especially in rock glaciers, vegetation cover increases with the decrease in movement and the percentage growth of finer granulometry (Burga et al., 2004; Cannone and Gerdol, 2003; Colombo et al., 2016; Giaccone et al., 2019). For this reason, relict rock glaciers are generally colonized by grasslands and shrubs, while active/inactive rock glaciers are colonized by a few and scattered individuals of pioneer communities that can reach locally more extended cover thanks to their stress-tolerance capacity.

Under the ongoing climate change (Beniston et al., 2018), mountain ecosystems are facing modifications in both geomorphic processes and vegetation communities. While an increase in species richness and an upward shift of plant species at high altitudes during the last century have already been assessed in various studies (Cannone et al., 2007; Stöckli et al., 2011; Wipf et al., 2013), as well as a shift of the treeline to higher elevations and latitudes (Garamvoelgyi and Hufnagel, 2013), studies on the future impact of geomorphic processes on vegetation (for example Masseroli et al., 2016) are sporadic. An augmentation of the morainic deposits due to the accelerated glacier retreat, an increase in landslides and 
rockfall due to permafrost degradation, and a greater infiltration of water because of the increase in liquid precipitation can be expected (IPCC, 2018). Therefore, it is difficult to quantify the intensity of these phenomena and their impact on plant biodiversity. We expected a continual upward shift of plant species to the summit of the mountains, risking the disappearance of some nival species where no higher habitats are available (Steinbauer et al., 2018). Stabilization in some areas (e.g. ancient morainic deposits and rock glaciers) and destabilization in others (e.g. proglacial areas, talus slopes) would keep a heterogeneous mosaic of microhabitats suitable for the conservation of different plant communities.

\section{Assessment of the ecological value of geomorphosites - methodological proposal}

The evaluation of the ecological value of dynamic geomorphosites should consider their capacity to maintain a high degree of biodiversity. The literature review showed two approaches. The first one, which is by far the most frequently used (e.g. Bruschi and Cendrero, 2005; Pralong, 2005), aims to give a high ecological value to sites where biodiversity is high or where interesting or rare species are present. However, the presence of a plant community of high interest does not mean that the ecological value of the associated geomorphosite is necessarily high, as this high interest may be due to factors other than the geomorphological features. The second approach, suggested by Bollati et al. (2015), tries to assess if the ecosystem is influenced or determined by specific geomorphological features.

Here we present a third numeric approach focused on vegetation diversity that combines the first two ones and tries to answer the following question: is the high biodiversity or the presence of rare species observed on a geomorphosite linked to specific geomorphological conditions? If the answer is yes, we consider that the ecological value of the geomorphosite is high. In the next lines, we explain how this approach works.

We propose an evaluation of the ecological value of geomorphosites based on two groups of numeric criteria: criteria for assessing the interest of the plant community and criteria for determining the influence of geomorphological processes on vegetation (see Table 1). The first group of criteria, concerning the interest of the plant community (with scores ranging from 0 to 6 ), is assessed according to the sum of two criteria (ranging from 0 to 3 ): (1) the diversity of plant species and (2) the presence of rare or protected species (after Bollati et al., 2018, 2019). The second group of criteria, used to determine the influence of geomorphological processes, is based on the morphodynamics index of Giaccone et al. (2019), ranging from 0 to 9. It is composed of three criteria (frequency of disturbances, surface of movement and soil) which allow a comprehensive evaluation of the influence of geomorphological processes on vegetation.
Finally, the ecological value is calculated summing the scores from both groups of criteria. The ecological value can therefore be low (0-5), medium (6-10) or high (11-15).

\subsection{Diversity and rareness of species}

The numerical assessment of plant diversity (number of different species) and of the rareness of plant species is illustrated in Table 2. The number of species must be counted or estimated for the entire landform surface.

This evaluation is closely linked to the spatial scale considered. Species diversity is likely to be higher if the area under consideration is larger, especially if a larger scale allows the presence of multiple habitats and varied environmental conditions. Similarly, a locally rare species is not necessarily rare at a regional or national level. It is therefore important to specify the scale of analysis: is the plant community of interest on the scale of a slope, a valley, a region or a country? Are the protected species mentioned in a regional, national or international list of protected species? Besides, a distinction has to be made between rare and protected species, as not all rare species are protected and vice versa, but the protection given to a particular species is very often linked to its rareness.

\subsection{Geomorphological processes}

The numerical evaluation of the influence of the geomorphological processes is based on the morphodynamics index (Giaccone et al., 2019) reported in Table 3. The existence of disturbances that affect the soil can be related to numerous geomorphological processes: a movement in the surface may be induced by periglacial processes, solifluction or frost weathering; the erosion of surface deposits or the deposition of sediments may be linked to gravitational processes, avalanches, post-glacial decompression, torrential activity, etc. The frequency and intensity of these perturbations are key factors to understanding the impacts they can have on soil development and vegetation (Masseroli et al., 2020). Because they limit the development of the soil and can damage vegetation, disturbances may reduce the number of plant species. Nevertheless, at the same time, they act as a renovator and allow the existence of pioneer species which would otherwise have been replaced by alpine grassland or by other species adapted to stable terrain. Giaccone et al. (2019) suggested that the application of a morphodynamics index can lead to fundamental results for estimating in which areas the vegetation communities are subject to a stronger geomorphic pressure. This index evaluates the frequency of the geomorphic disturbances (score from 0 to 4 ), the landform stability (measured with geomorphological interpretation or comparison between images when possible; the score is 0 or 1) and the soil development (score from 0 to 4 ). The sum of the three criteria ranges from 0 (stable landform) to 9 (landforms affected by high activity). 
Table 1. Proposed criteria for assessing the ecological value of geomorphosites.

\begin{tabular}{l|ll}
\hline \multicolumn{2}{c}{ Ecological value of geomorphosites - assessment criteria for vegetation diversity } \\
\hline Interest of plant community & $\begin{array}{c}\text { Influence of geomorphological processes } \\
\text { (morphodynamics index) }\end{array}$ \\
\hline Diversity of species $\quad$ Species richness & $\begin{array}{l}\text { Disturbances } \\
\text { oxistence, frequency and intensity } \\
\text { of disturbances induced by } \\
\text { geomorphological processes }\end{array}$ \\
\hline Rareness of species $\quad$ Presence of rare or protected plant species & $\begin{array}{l}\text { Surface movement } \\
\text { Is the landform stable or not? }\end{array}$ \\
\hline & $\begin{array}{l}\text { Soil } \\
\text { (granulometry, superficial } \\
\text { formations, soils) resulting from } \\
\text { geomorphological features }\end{array}$ \\
\hline
\end{tabular}

Table 2. Numerical assessment of the interest of plant communities. The diversity of species is also called species richness. To evaluate the rareness or the protection status of a species, regional or national lists have to be consulted.

\begin{tabular}{lllll}
\hline & \multicolumn{4}{c}{ Interest of plant community } \\
\cline { 2 - 5 } & 0 & 1 & 2 & 3 \\
\hline Diversity of species & Very few species (0-10 species) & Few species (11-20) & Some species (21-30) & Many species ( $\geq 31)$ \\
\hline Rareness of species & $\begin{array}{l}\text { No rare or protected } \\
\text { species }\end{array}$ & $\begin{array}{l}\text { One rare or protected } \\
\text { species }\end{array}$ & $\begin{array}{l}\text { Some rare or protected } \\
\text { species (2-4) }\end{array}$ & $\begin{array}{l}\text { Many rare or protected } \\
\text { species }(\geq 5)\end{array}$ \\
\hline
\end{tabular}

Table 3. Guidelines to assess the morphodynamics index (from Giaccone et al., 2019).

\begin{tabular}{llllll}
\hline & \multicolumn{5}{c}{ Morphodynamics index } \\
\cline { 2 - 6 } & 0 & 1 & 2 & 3 & 4 \\
\hline $\begin{array}{l}\text { Frequency of } \\
\text { disturbances }\end{array}$ & $\begin{array}{l}\text { Absence of } \\
\text { disturbances }\end{array}$ & $\begin{array}{l}\text { Return time of } \\
\text { disturbances }> \\
10 \text { years }\end{array}$ & $\begin{array}{l}\text { Return time of } \\
\text { disturbances }< \\
10 \text { years }\end{array}$ & $\begin{array}{l}\text { Annual } \\
\text { disturbances }\end{array}$ & $\begin{array}{l}\text { Several times in } \\
1 \text { year }\end{array}$ \\
\hline Surface movement & No movement & $\begin{array}{l}\text { Movement } \\
\text { (cm/year-dm/year) }\end{array}$ & - & - & - \\
\hline Soil & $\begin{array}{l}\text { Developed } \\
\text { soil, dominated } \\
\text { by fine } \\
\text { material }\end{array}$ & $\begin{array}{l}\text { Developed fine } \\
\text { soil material } \\
\text { with rock } \\
\text { texture }\end{array}$ & $\begin{array}{l}\text { Sparse fine soil } \\
\text { material and } \\
\text { rock texture }\end{array}$ & $\begin{array}{l}\text { Rock texture } \\
\text { with poor fine } \\
\text { material }\end{array}$ & $\begin{array}{l}\text { Absence of } \\
\text { fine material }\end{array}$ \\
& & & & \\
\end{tabular}

\subsection{Ecological value}

This approach can be applied to small surfaces, such as for example at a plot scale, or directly at the scale of a landform. As our aim is to provide a method that can be used at the scale of a geomorphosite, we suggest carrying out multiple plots to cover all the extension of the landform, allowing reaching its intrinsic variability.

The interest of plant communities for the entire landform is calculated by the sum of all species present on the landform but by counting only once the species that occur several times in different plots. For the morphodynamics index at the scale of a landform, first calculated at the plot level, we consider the maximum of the values measured on each plot.
Finally, both values are added together to obtain the ecological value, as summarized in the following formula:

Interest of plant communities (0-6)

$=$ diversity of species $(0-3)+$ rareness of species $(0-3)$

Morphodynamics index (0-9)

$=$ disturbances $(0-4)+$ surface movement $(0-1)$

+ soil (0-4)

Ecological value (0-15)

$=$ interest of plant communities (0-6)

+ max morphodynamics index (0-9).

Ecological value from 0 to 5 indicates a low value, from 6 to 10 a moderate value and from 11 to 15 a high value. 


\section{Case study}

In this section, we illustrate the use of the criteria defined above to assess the ecological value of three geomorphosites and a talus slope located in a mountain environment. Les Martinets Glacier area is in the upper part of a valley called the Vallon de Nant, in the western Swiss Alps (Fig. 1). The glacier lies at the foot of the high north rock walls of the Dent de Morcles that culminate at $2968 \mathrm{~m}$ a.s.l. Different moraine ridges built by this glacier and other gravitational and periglacial deposits fill the bottom of the valley in its upper part down to an altitude of about $2000 \mathrm{~m}$. In the context of high geomorphological diversity such as in Les Martinets Glacier area, various landforms can be found, such as pre-Little Ice Age (LIA) moraines (Lambiel et al., 2008; the exact period of formation of these moraines has not been clearly defined in previous studies), LIA moraines (1350$1860 \mathrm{CE}$ ), rock glaciers, talus slopes and rockfall/avalanche deposits (Perret and Martin, 2015). To apply the ecological value evaluation criteria proposed in the previous section, we selected three geomorphosites and a talus slope (Fig. 2). The three geomorphosites are the LIA moraine of Les Martinets Glacier, which is now partly separated from the ice because of glacier retreat; a pre-LIA moraine complex located just outside the limits of the LIA maximum glacier extent; and a rock glacier fed by sediments from these moraine deposits and ancient rockfalls. We consider that these three landforms are geomorphosites because they have a high geoscientific value. They are intact, are representative of glacial and periglacial landforms that can be found in the Alps at this altitude, and allow significant understanding of the past extent of the cryosphere and of the evolution of the landscape in the upper part of the valley since the end of the Younger Dryas. We could also consider that all three sites together form a "geomorphological system", after the classification of Grandgirard (1997b), but as they have different characteristics regarding their age and dynamics, it is more interesting to consider them separately. Besides, we choose to also evaluate the ecological value of a talus slope in the same area. With no relevant palaeogeographical interest, this talus slope has little geoscientific value, and we therefore do not consider it a geomorphosite. However, as it is under similar environmental conditions to the three other sites but is formed by different geomorphological processes, the comparison is interesting and provides a further example of the use of the method.

In each landform, we have selected between two and six plots of $2 \times 2 \mathrm{~m}$ each, with relative information concerning species richness and the morphodynamics index, based on the availability of field data from Giaccone et al. (2019). As the plots are located in different landforms (Fig. 2), they are affected by various frequencies and intensities of dynamics and disturbances.

Plot nos. 1-4 are located on a talus slope composed of blocks varying from centimetric to pluri-decimetric size with

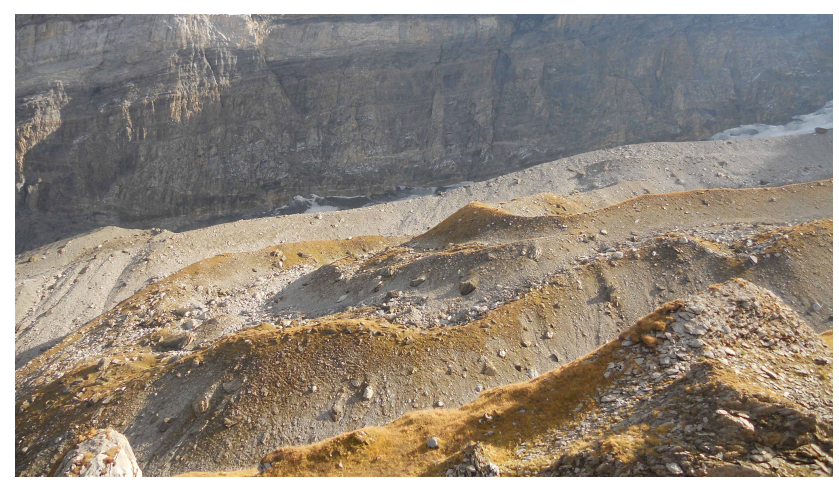

Figure 1. Les Martinets glacier foreland, in the upper part of the Vallon de Nant, western Swiss Alps. The diversified glacial and periglacial landforms and related dynamic processes create various habitats for pioneer species. Photo: Jonathan Bussard.

a low content of fine-grained mineral material (Fig. 3a). Some parts of it are vegetated because the lower frequency of disturbances allowed the growth of plant species. The plant community is characterized by pioneer species (e.g. Thlaspi rotundifolium, Saxifraga biflora and Pritzelago alpina) with a scarce cover percentage in debris areas. Where vegetation is denser, alpine meadows with Sesleria caerulea and Festuca violacea occupy large areas. In the transition between these two environments, the coexistence of pioneer species and stable species is prevalent.

Plot nos. 5-10 are situated on the rock glacier, the first three on the lower lobe, presenting no activity, and the last three on the upper lobe, presenting low activity in its frontal part (Fig. 3b; the degree of activity of the rock glacier is based on geomorphological observations and confirmed by the morphodynamics index). On both lobes, the blocks are bigger, with the presence of metric boulders and fine-grained mineral material, which is augmented on the lower lobe. Differences in vegetation composition were clearly demonstrated in Giaccone et al. (2019): the lower lobe has vegetation patches of late successional stages (grassland), whereas the upper part is colonized exclusively by pioneer species (e.g. Thlaspi rotundifolium and Pritzelago alpina).

Plot nos. 11-15 are positioned in the pre-LIA morainic complex, in the external, internal and crest position. Here vegetation varies substantially within a few metres. In the crest position, the soil is fully developed and dominated by fine organic material, allowing the presence of grassland characterized by Sesleria caerulea, a typical species of dry calcareous grassland, and by higher species richness (Fig. 3c). On slopes and internal parts, vegetation is constituted by pioneer species. The granulometry is composed of blocks varying from centimetric to pluri-decimetric size with a low content of fine-grained mineral material.

The last two plots (nos. 16 and 17) are on the ridge of the LIA moraine. The vegetation cover and the species richness are lower, but the plant community is in transition from a 


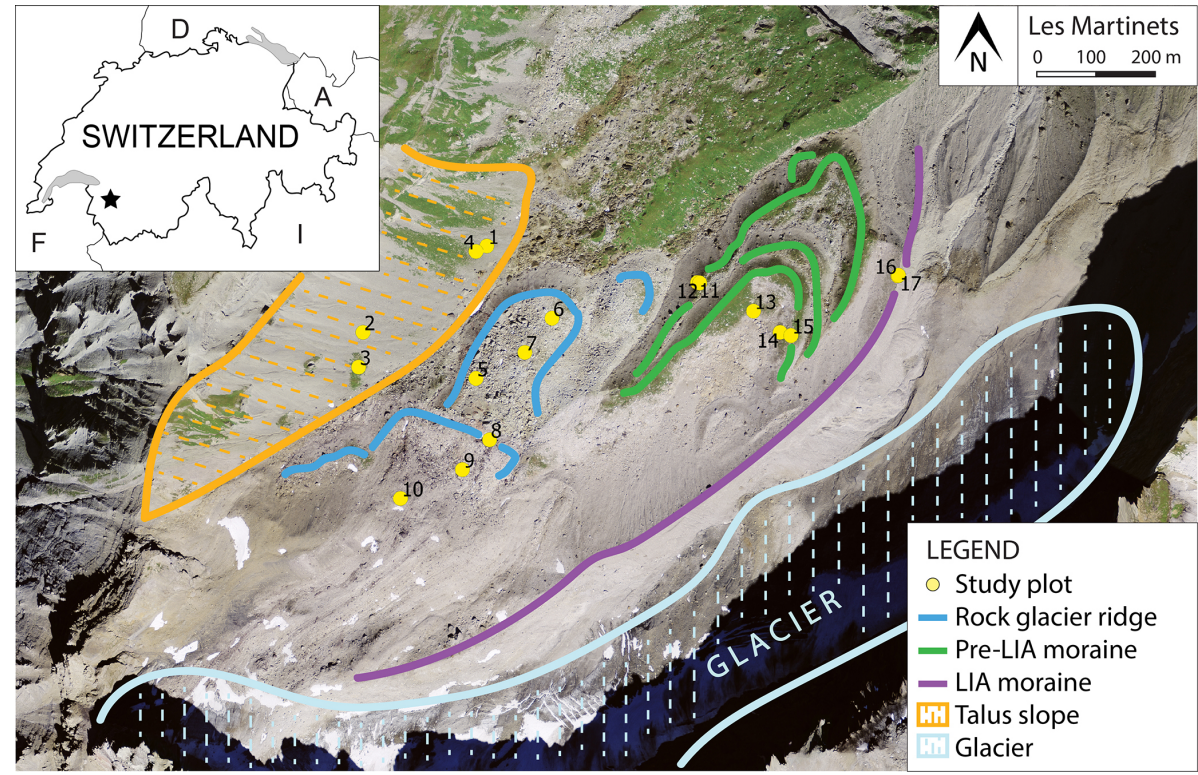

Figure 2. Study area and location of the plots chosen for the assessment of the ecological value. Orthophotos: SWISSIMAGE, (C) swisstopo, 2020 .

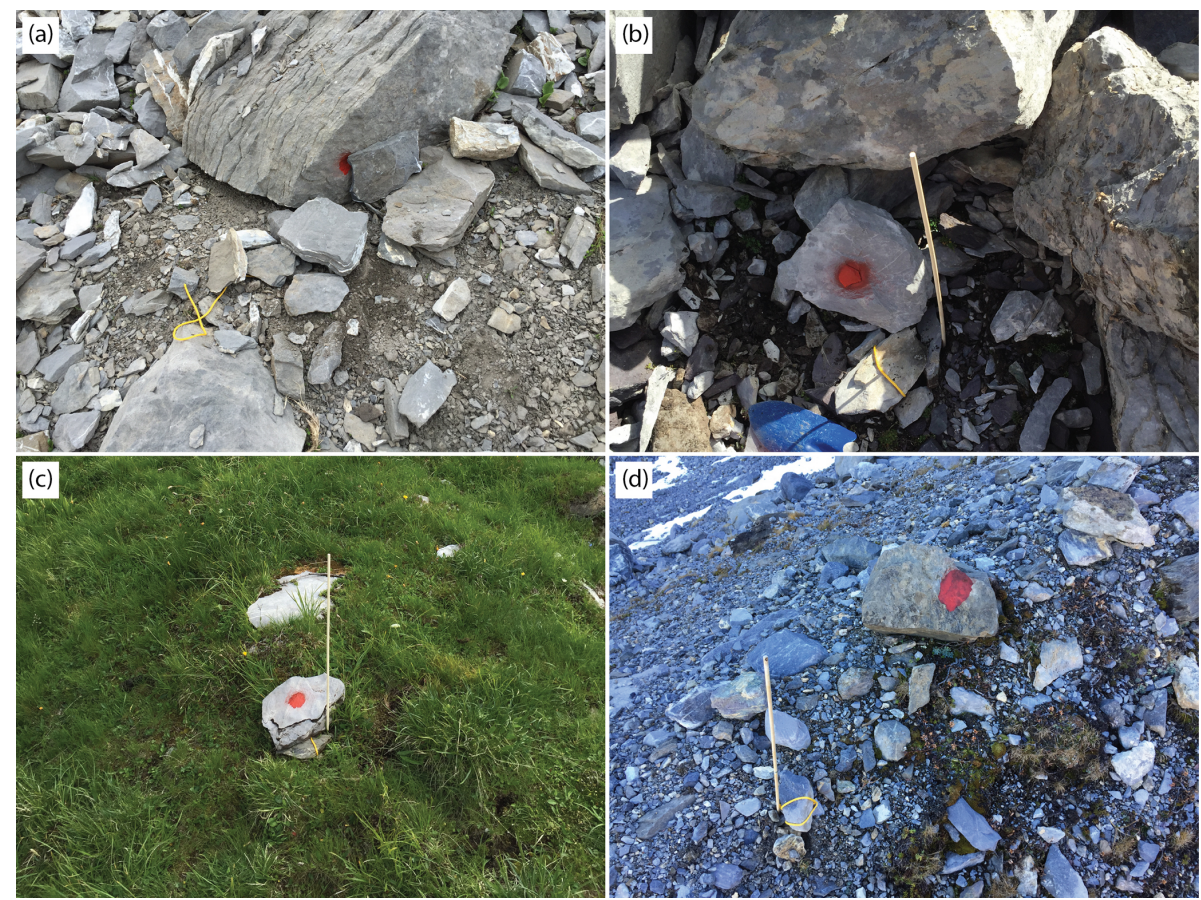

Figure 3. The main characteristics of the landforms: (a) plot no. 2 on the talus slope; (b) plot no. 8 on the upper lobe of the rock glacier; (c) plot no. 15 on the ridge of the pre-LIA moraines; (d) plot no. 16 on the ridge of the LIA moraine. Photos: Elisa Giaccone.

pioneer state to a more developed community, thanks to the presence of individuals of Salix retusa. The grain size is characterized by gravels $(2-20 \mathrm{~mm})$ and cobbles $(20-200 \mathrm{~mm})$, with a high content of fine-grained minerals and organic material. A few blocks (pluri-decimetric size) are present on the surface (Fig. 3d).
The data gathered in each plot are summarized in Table 4. Successively, we calculated all the criteria at a landform scale, counting only once species occurrence and their protection status and taking the maximum value for the morphodynamics index. The protection status was checked according to existing cantonal (regional) and federal (national) laws 
Table 4. Selected plots in Les Martinets. The morphodynamics index refers to the index calculated in Giaccone et al. (2019). It results from the sum of the frequency of disturbances ( 0 , absence of disturbances, to 4 , several disturbances in 1 year), surface movement $(0$, no movement; 1 , movement) and soil development ( 0 , developed soil dominated by fine material, to 4 , absence of fine material). Species richness is the number of species per plot. LIA denotes Little Ice Age.

\begin{tabular}{|c|c|c|c|c|c|c|c|c|c|c|}
\hline Plot & Landform & $\begin{array}{l}\text { Coordinates } X, Y \\
(\mathrm{CH} 1903 / \mathrm{LV} 03)\end{array}$ & $\begin{array}{l}\text { Elevation } \\
\text { (m) }\end{array}$ & $\begin{array}{r}\text { Aspect } \\
\left({ }^{\circ}\right)\end{array}$ & $\begin{array}{l}\text { Slope } \\
(\%)\end{array}$ & $\begin{array}{l}\text { Frequency of } \\
\text { disturbances }\end{array}$ & $\begin{array}{c}\text { Surface } \\
\text { movement }\end{array}$ & $\begin{array}{c}\text { Soil } \\
\text { development }\end{array}$ & $\begin{array}{l}\text { Morphodynamics } \\
\text { index }\end{array}$ & $\begin{array}{r}\text { Species } \\
\text { richness } \\
\text { (no.) }\end{array}$ \\
\hline 1 & Talus slope & 572225,117665 & 2311 & 99 & 18 & 4 & 0 & 3 & 7 & 18 \\
\hline 2 & Talus slope & 571997,117506 & 2392 & 90 & 28 & 3 & 1 & 4 & 8 & 10 \\
\hline 3 & Talus slope & 571989,117442 & 2391 & 109 & 38 & 1 & 0 & 0 & 1 & 15 \\
\hline 4 & Talus slope & 572205,117655 & 2316 & 113 & 19 & 1 & 0 & 1 & 2 & 14 \\
\hline 5 & Rock glacier & 572205,117421 & 2362 & 345 & 24 & 0 & 0 & 3 & 3 & 7 \\
\hline 6 & Rock glacier & 572345,117532 & 2335 & 24 & 17 & 0 & 0 & 2 & 2 & 20 \\
\hline 7 & Rock glacier & 572295,117469 & 2363 & 37 & 12 & 0 & 0 & 2 & 2 & 12 \\
\hline 8 & Rock glacier & 572230,117308 & 2395 & 26 & 34 & 4 & 1 & 3 & 8 & 6 \\
\hline 9 & Rock glacier & 572180,117253 & 2418 & 64 & 27 & 1 & 0 & 3 & 4 & 9 \\
\hline 10 & Rock glacier & 572066,117200 & 2465 & 13 & 32 & 1 & 0 & 3 & 4 & 9 \\
\hline 11 & Pre-LIA moraines & 572613,117598 & 2271 & 308 & 39 & 1 & 0 & 2 & 3 & 10 \\
\hline 12 & Pre-LIA moraines & 572617,117597 & 2273 & 353 & 17 & 0 & 0 & 0 & 0 & 24 \\
\hline 13 & Pre-LIA moraines & 572716,117545 & 2257 & 170 & 28 & 1 & 0 & 1 & 2 & 15 \\
\hline 14 & Pre-LIA moraines & 572765,117506 & 2277 & 298 & 40 & 1 & 0 & 2 & 3 & 13 \\
\hline 15 & Pre-LIA moraines & 572785,117500 & 2290 & 16 & 14 & 0 & 0 & 0 & 0 & 17 \\
\hline 16 & LIA moraine & 572982,117610 & 2259 & 185 & 21 & 1 & 0 & 1 & 2 & 18 \\
\hline 17 & LIA moraine & 572983,117611 & 2259 & 51 & 15 & 1 & 0 & 2 & 3 & 8 \\
\hline
\end{tabular}

Table 5. Ecological values and their criteria for the four selected landforms in Les Martinets. The interest of plant community results from the sum of the diversity of species (ranging from 0 to 3 ) and rareness of species (ranging from 0 to 3 ). The ecological value is the sum of the morphodynamics index and interest of plant communities. LIA denotes Little Ice Age.

\begin{tabular}{lccccccr}
\hline Landform & $\begin{array}{c}\text { Morphodynamic } \\
\text { index (max) }\end{array}$ & $\begin{array}{c}\text { Species } \\
\text { richness } \\
\text { (no.) }\end{array}$ & $\begin{array}{c}\text { Diversity } \\
\text { of species }\end{array}$ & $\begin{array}{c}\text { Protected } \\
\text { species } \\
\text { (no.) }\end{array}$ & $\begin{array}{c}\text { Rareness } \\
\text { of species }\end{array}$ & $\begin{array}{c}\text { Interest } \\
\text { of plant } \\
\text { community }\end{array}$ & $\begin{array}{r}\text { Ecological } \\
\text { value }\end{array}$ \\
\hline Talus slope & 8 & 36 & 3 & 0 & 0 & 3 & 11 \\
Rock glacier & 8 & 37 & 3 & 4 & 2 & 5 & 8 \\
Pre-LIA moraines & 3 & 46 & 3 & 3 & 2 & 5 & 8 \\
LIA moraine & 3 & 20 & 1 & 2 & 2 & 3 & 6 \\
\hline
\end{tabular}

(the protection status of a plant species can be checked on the website https://www.infoflora.ch/en/, last access: 30 September 2021) and the national red list of threatened plants (Bornand et al., 2016). Once we obtained two values for each criterion and for each landform, we summed them to find the ecological value (Table 5).

According to the results presented in Table 5, the talus slope and the rock glacier have a high ecological value (values 11 and 13, respectively). Instead, the pre-LIA moraine and LIA moraine geomorphosites have moderate ecological value (values 8 and 6). Looking in more detail, the first two landforms are characterized by a high morphodynamics index: the frequency of disturbances and the absence of organic soil are the parameters that condition the high score more. In addition to that, one of the plots of the rock glacier is located at the front of the upper lobe, which is in movement. The species richness is high on both landforms because both grasslands and pioneer species colonize these areas. The presence of four protected species in the rock glacier is re- markable: Epilobium anagallidifolium, Linaria alpina, Saxifraga oppositifolia and $S$. paniculata have been protected since 2005 at a cantonal level. In contrast, no protected or rare species are present in the talus slope, and that explains why the talus slope has a lower ecological value than the rock glacier.

The pre-LIA and LIA moraines present lower values of the morphodynamics index because they are not subject to movement; they have a low percentage of disturbances; and the soil contains abundant organic material in many plots, especially on the ridge of the pre-LIA moraines. On the pre-LIA moraines, species richness is the most abundant (46 species) and three protected species can be found (Epilobium anagallidifolium, Saxifraga oppositifolia and Vaccinium uliginosum; the latter is considered "Near Threatened (NT)" according to the IUCN criteria). LIA moraines have a lower species richness (20 species), but two other species protected at a cantonal level (Linaria alpina and Saxifraga paniculata) are present. For these two landforms, the low morphodynam- 
ics index mainly explains why the ecological value is lower than for the two other landforms, which are more affected by geomorphological processes.

In all plots, we observe connections between the degree of stabilization of a landform and the resulting plant colonization processing. In landforms where the geomorphological processes are still active (i.e. plot nos. 1, 2 and 8), only a few species, the pioneer species, manage to colonize the area. In contrast, more stable landforms, such as the surfaces that have been free of glacier ice since the end of the Younger Dryas (i.e. plot nos. 3, 12 and 15) are colonized by alpine grassland with developed communities. Furthermore, some plant species, called ecosystem engineers, can help in the stabilization of landforms and, at the same time, act as a plant nursery for other plant species. This is the case for example for Dryas octopetala, an Arctic-alpine species living in calcareous soils that with its low stems, branches and numerous leaves, forms mats which accumulate fine sediments, biomass and humus and store moisture (Körner, 2003). This species was studied by Eichel et al. $(2016,2017)$, who demonstrated that, after a natural and initial decrease in geomorphic activities, D. octopetala starts to colonize the ground, promotes further the decrease in geomorphic activities and the formation of turf-banked solifluction landforms thanks to its morphology, and finally facilitates the colonization of other species acting as a nurse plant (Klanderud and Totland, 2004).

\section{Discussion and conclusion}

The aim of this article was to discuss the methodology for assessing the ecological value of dynamic mountain geomorphosites. We proposed lines of thought and evaluation criteria concerning one aspect of ecological value: the diversity of vegetation. We demonstrated that the approach based only on plant diversity (e.g. Bruschi and Cendrero, 2005; Pralong, 2005) does not provide a complete and objective assessment of the ecological value because all the information resulting from the dynamics of geomorphosites is lacking. An indication of the number of species (species richness) and the presence of rare or protected species is indeed not sufficient to give an assessment of ecological value, as it does not provide information on the role of geomorphological forms and processes in the formation and maintenance of specific plant communities. For this reason, it is important to consider multiple criteria that also take into consideration the influence of geomorphological processes (as shown in Bollati et al., 2015) and to carry out an evaluation at a landform level. We therefore proposed to measure the influence of geomorphological processes on plant diversity and on the conditions of the existence of rare species with regard to three criteria: disturbances, movement and soil, regrouped in the morphodynamics index (Giaccone et al., 2019). The dynamics of geomorphological processes (erosion and sediment deposition, slope movements) causes continual micro-changes in ground surfaces, which modify the plant diversity and help in establishing mechanisms of interactions between plant communities and geomorphic processes. This geomorphological disturbance acts as a renovator of habitats and allows the coexistence of different plant species in a small surface. Disturbances of high intensity or high frequency generally reduce the number of species because they limit the development of the soil and can damage vegetation. On the other hand, these constraints allow the existence of pioneer species that would not necessarily have found suitable conditions without geomorphological disturbances. The ecological value of dynamic mountain geomorphosites therefore lies, on the one hand, in the fact that they make it possible to create a variety of microhabitats and thus favour the existence of many different species and, on the other hand, in the maintenance of pioneer species that would no longer exist without disturbances by various geomorphological processes. The ecological value must also be put into perspective according to the scale considered for the analysis of these parameters; an ecological value of national importance can only exist if the geomorphological forms and processes condition the existence of rare or protected species on the scale of an entire country.

We illustrated the use of these criteria at the scale of the upstream part of a small alpine valley (Vallon de Nant, western Swiss Alps) for three geomorphosites - a rock glacier, a moraine complex from the pre-LIA, and a side and frontal moraine from the LIA - and for a zone of scree slopes and avalanche deposits. On each site, plots of $2 \times 2 \mathrm{~m}$ were analysed in order to have precise knowledge of the vegetation composition, and the results were assembled at a landform scale. The results showed that the pre-LIA moraine complex has a much higher species richness than the three other sites, and this is due to the absence of frequent or intense geomorphological disturbances. On the other hand, the three other sites are characterized by the presence of pioneer species, which have an interest at a local scale. Species protected at cantonal and national level were found on the rock glacier, on the pre-LIA moraine and on the LIA moraine, but no protected species were found on the talus slope. In summary, we concluded that the ecological value of the pre-LIA moraines and the LIA moraines is medium and that the ecological value of the rock glacier and the talus slope is high because, in all four sites, the heterogeneity of landforms and geomorphological processes allows the presence of various plant communities able to survive different degrees of disturbances in a limited area.

More generally, as some geomorphological processes and landforms permit the existence of pioneer species or a high degree of biodiversity, the ecological value of geomorphosites should be better taken into consideration in nature conservation policies or in environmental impact studies. In order to facilitate this, we believe that the geomorphosite evaluation process should better integrate the influence of geomorphological parameters on the creation and maintenance 
of specific conditions for plant communities and not focus only on the geoscientific or aesthetic values. In this case, we would like to underline the importance of collaboration between scientists from different disciplines to keep a strong relationship between geodiversity and biodiversity management and protection, since they are strongly correlated.

Code availability. The code is not published, but all methodological details about the calculation of the morphodynamics index can be found in Giaccone (2020), available in University of Lausanne open archives: https://serval.unil.ch/en/notice/serval: BIB_EF887773E615 (last access: 4 October 2021).

Data availability. Field data can be accessed in Giaccone et al. (2019) and Giaconne (2020).

Author contributions. JB designed and conceptualized the overall research objectives and wrote the first draft. EG realized the field investigations and contributed to developing the analysis and arguments.

Competing interests. The authors declare that they have no conflict of interest.

Disclaimer. Publisher's note: Copernicus Publications remains neutral with regard to jurisdictional claims in published maps and institutional affiliations.

Acknowledgements. We would like to thank Emmanuel Reynard for his valuable and detailed remarks and comments, Christophe Lambiel for his general remarks, the two anonymous referees for their very valuable remarks and comments, and Cristian Scapozza for the editing of this article.

Review statement. This paper was edited by Cristian Scapozza and reviewed by two anonymous referees.

\section{References}

Anderson, M. G. and Ferree, C. E.: Conserving the Stage: Climate Change and the Geophysical Underpinnings of Species Diversity, PLOS One, 5, e11554, https://doi.org/10.1371/journal.pone.0011554, 2010.

Atkinson, C. L., Allen, D. C., Davis, L., and Nickerson, Z. L.: Incorporating ecogeomorphic feedbacks to better understand resiliency in streams: A review and directions forward, Geomorphology, 305, 123-140, https://doi.org/10.1016/j.geomorph.2017.07.016, 2018.

Beier, P. and Brost, B.: Use of Land Facets to Plan for Climate Change: Conserving the Arenas, Not the Actors, Conserv. Biol.,
24, 701-710, https://doi.org/10.1111/j.1523-1739.2009.01422.x, 2010.

Beniston, M., Farinotti, D., Stoffel, M., Andreassen, L. M., Coppola, E., Eckert, N., Fantini, A., Giacona, F., Hauck, C., Huss, M., Huwald, H., Lehning, M., López-Moreno, J.-I., Magnusson, J., Marty, C., Morán-Tejéda, E., Morin, S., Naaim, M., Provenzale, A., Rabatel, A., Six, D., Stötter, J., Strasser, U., Terzago, S., and Vincent, C.: The European mountain cryosphere: a review of its current state, trends, and future challenges, The Cryosphere, 12, 759-794, https://doi.org/10.5194/tc-12-759-2018, 2018.

Bétard, F.: Géodiversité, biodiversité et patrimoines environnementaux. De la connaissance à la conservation et à la valorisation, Mémoire d'Habilitation à Diriger des Recherches, Université Paris-Diderot, Paris, 2017.

Bollati, I., Leonelli, G., Vezzola, L., and Pelfini, M.: The role of Ecological Value in Geomorphosite assessment for the DebrisCovered Miage Glacier (Western Italian Alps) based on a review of 2.5 centuries of scientific study, Geoheritage, 7, 119-135, https://doi.org/10.1007/s12371-014-0111-2, 2015.

Bollati, I., Crosa Lenz, B., Golzio, A., and Masseroli, A.: Tree rings as ecological indicator of geomorphic activity in geoheritage studies, Ecol. Indic., 93, 899-916, https://doi.org/10.1016/j.ecolind.2018.05.053, 2018.

Bollati, I., Masseroli, A., Mortara, G., Pelfini, M., and Trombino, L.: Alpine gullies system evolution: erosion drivers and control factors. Two examples from the western Italian Alps, Geomorphology, 327, 248-263, https://doi.org/10.1016/j.geomorph.2018.10.025, 2019.

Bornand, C., Gygax, A., Juillerat, P., Jutzi, M., Möhl, A., Rometsch, S., Sager, L., Santiago, H., and Eggenberg, S.: Liste rouge Plantes vasculaires. Espèces menacées en Suisse, Office fédéral de l'environnement, Berne and Info Flora, Geneva, 2016.

Brilha, J.: Geoconservation and protected areas, Environ. Conserv., 29, 273-276, https://doi.org/10.1017/S0376892902000188, 2002.

Brilha, J.: Geoheritage: Inventories and Evaluation, in: Geoheritage, edited by: Reynard, E. and Brilha, J., Elsevier, Amsterdam, 69 85, https://doi.org/10.1016/B978-0-12-809531-7.00004-6, 2018.

Brilha, J., Gray, M., Pereira, D. I., and Pereira, P.: Geodiversity: An integrative review as a contribution to the sustainable management of the whole of nature, Environ. Sci. Policy, 86, 19-28, https://doi.org/10.1016/j.envsci.2018.05.001, 2018.

Bruschi, V. M. and Cendrero, A.: Geosite evaluation; can we mesure intangible values?, Il Quaternario, 18, 293-306, 2005.

Burga, C. A., Frauenfelder, R., Ruffet, J., Hoelzle, M., and Kääb, A.: Vegetation on Alpine rock glacier surfaces: a contribution to abundance and dynamics on extreme plant habitats, Flora, 199, 505-515, https://doi.org/10.1078/0367-2530-00179, 2004.

Burga, C. A., Krüsi, B., Egli, M., Wernli, M., Elsener, S., Ziefle, M., Fischer, T., and Mavris, C.: Plant succession and soil development on the foreland of the Morteratsch glacier (Pontresina, Switzerland): Straight forward or chaotic?, Flora, 205, 561-576, https://doi.org/10.1016/j.flora.2009.10.001, 2010.

Buri, A., Cianfrani, C., Pinto-Figueroa, E., Yashiro, E., Spangenberg, J. E., Adatte, T., Verrecchia, E., Guisan, A., and Pradervand, J.-N.: Soil factors improve predictions of plant species distribution in a mountain environment, Prog. Phys. Geogr., 41, 703-722, https://doi.org/10.1177/0309133317738162, 2017. 
Butler, D. R.: Zoogeomorphology: animals as geomorphic agents, Cambridge University Press, Cambridge, New York, 1995.

Cannone, N. and Gerdol, R.: Vegetation as an ecological indicator of surface instability in rock glaciers, Arct. Antarct. Alp. Res., 35, 384-390, 2003.

Cannone, N., Sgorbati, S., and Guglielmin, M.: Unexpected impacts of climate change on alpine vegetation, Front. Ecol. Environ., 5, 360-364, 2007.

Carcavilla, L., Durán, J. J., García-Cortés, Á., and LópezMartínez, J.: Geological Heritage and Geoconservation in Spain: Past, Present, and Future, Geoheritage, 1, 75-91, https://doi.org/10.1007/s12371-009-0006-9, 2009.

Cocean, G. and Cocean, P.: An Assessment of Gorges for Purposes of Identifying Geomorphosites of Geotourism Value in the Apuseni Mountains (Romania), Geoheritage, 9, 71-81, https://doi.org/10.1007/s12371-016-0180-5, 2017.

Colombo, N., Giaccone, E., Paro, L., Buffa, G., and Fratianni, S.: The recent transition from glacial to periglacial environment in a high altitude alpine basin (Sabbione basin, northwestern Italian Alps). Preliminary outcomes from a multidisciplinary approach, Geogr. Fis. Din. Quat., 39, 21-36, https://doi.org/10.4461/GFDQ.2016.39.3, 2016.

Coratza, P. and Hobléa, F.: The specificities of geomorphological heritage, in: Geoheritage, edited by: Reynard, E. and Brilha, J., Elsevier, Amsterdam, 87-106, https://doi.org/10.1016/B9780-12-809531-7.00005-8, 2018.

Corenblit, D., Tabacchi, E., Steiger, J., and Gurnell, A. M.: Reciprocal interactions and adjustments between fluvial landforms and vegetation dynamics in river corridors: A review of complementary approaches, Earth-Sci. Rev., 84, 56-86, https://doi.org/10.1016/j.earscirev.2007.05.004, 2007.

Corenblit, D., Baas, A. C. W., Bornette, G., Darrozes, J., Delmotte, S., Francis, R. A., Gurnell, A. M., Julien, F., Naiman, R. J., and Steiger, J.: Feedbacks between geomorphology and biota controlling Earth surface processes and landforms: A review of foundation concepts and current understandings, Earth-Sci. Rev., 106, 307-331, https://doi.org/10.1016/j.earscirev.2011.03.002, 2011.

Crofts, R.: Promoting geodiversity: learning lessons from biodiversity, P. Geologist. Assoc., 125, 263-266, https://doi.org/10.1016/j.pgeola.2014.03.002, 2014.

Crofts, R.: Putting Geoheritage Conservation on All Agendas, Geoheritage, 10, 231-238, https://doi.org/10.1007/s12371-0170239-y, 2018.

Crofts, R., Gordon, J. E., Brilha, J., Gray, M., Gunn, J., Larwood, J., Santucci, V., Tormey, D., and Worboys, G. L.: Guidelines for geoconservation in protected and conserved areas, edited by: Groves, C., IUCN - International Union for Conservation of Nature, Gland, Switzerland, https://doi.org/10.2305/IUCN.CH.2020.PAG.31.en, 2020.

Crofts, R., Tormey, D., and Gordon, J. E.: Introducing New Guidelines on Geoheritage Conservation in Protected and Conserved Areas, Geoheritage, 13, 33, https://doi.org/10.1007/s12371-02100552-0, 2021.

Eichel, J., Corenblit, D., and Dikau, R.: Conditions for feedbacks between geomorphic and vegetation dynamics on lateral moraine slopes: a biogeomorphic feedback window, Earth Surf. Proc. Land., 41, 406-419, https://doi.org/10.1002/esp.3859, 2016.

Eichel, J., Draebing, D., Klingbeil, L., Wieland, M., Eling, C., Schmidtlein, S., Kuhlmann, H., and Dikau, R.: Solifluction meets vegetation: the role of biogeomorphic feedbacks for turf-banked solifluction lobe development, Earth Surf. Proc. Land., 42, 16231635, https://doi.org/10.1002/esp.4102, 2017.

Erikstad, L.: Geoheritage and geodiversity management - the questions for tomorrow, P. Geologist. Assoc., 124, 713-719, https://doi.org/10.1016/j.pgeola.2012.07.003, 2013.

Erschbamer, B., Niederfriniger Schlag, R., and Winkler, E.: Colonization processes on a central Alpine glacier foreland, J. Veg. Sci., 19, 855-862, https://doi.org/10.3170/2008-8-18464, 2008.

Eveillard-Buchoux, M., Beninger, P. G., Chadenas, C., and Sellier, D.: Small-scale natural landscape features and seabird nesting sites: the importance of geodiversity for conservation, Landscape Ecol., 34, 2295-2306, https://doi.org/10.1007/s10980019-00879-8, 2019.

Garamvoelgyi, A. and Hufnagel, L.: Impacts of climate change on vegetation distribution no. 1 climate change induced vegetation shifts in the palearctic region, Appl. Ecol. Environ. Res., 11, 79122, https://doi.org/10.15666/aeer/1101_079122, 2013.

Garavaglia, V., Pelfini, M., and Bollati, I.: The influence of climate change on glacier geomorphosites: the case of two Italian glaciers (Miage Glacier, Forni Glacier) investigated through dendrochronology, Géomorphologie, 16, 153-164, https://doi.org/10.4000/geomorphologie.7895, 2010.

Gentili, R., Armiraglio, S., Rossi, G., Sgorbati, S., and Baroni, C.: Floristic patterns, ecological gradients and biodiversity in the composite channels (Central Alps, Italy), Flora, 205, 388-398, https://doi.org/10.1016/j.flora.2009.12.013, 2010.

Gentili, R., Armiraglio, S., Sgorbati, S., and Baroni, C.: Geomorphological disturbance affects ecological driving forces and plant turnover along an altitudinal stress gradient on alpine slopes, Plant Ecol., 214, 571-586, https://doi.org/10.1007/s11258-0130190-1, 2013.

Gentizon, C.: La géomorphologie et les paysages dans les réserves naturelles: études de cas, in: Paysages géomorphologiques, Actes du séminaire de troisième cycle de géographie Paysages géomorphologiques, organisé par les Instituts de Géographie des Universités de Lausanne et Fribourg du 10 au 14 février et du 25 au 29 août 2003, Lausanne, 111-121, 2004.

Giaccone, E.: Geomorphological characteristics as preditors for vegetation models in Alpine environment, $\mathrm{PhD}$ thesis, Institute of Earth Surface Dynamics, University of Lausanne, https://serval. unil.ch/resource/serval:BIB_EF887773E615.P005/REF (last access: 4 October 2021), 2020.

Giaccone, E., Luoto, M., Vittoz, P., Guisan, A., Mariéthoz, G., and Lambiel, C.: Influence of microclimate and geomorphological factors on alpine vegetation in the Western Swiss Alps, Earth Surf. Proc. Land., 44, 3093-3107, https://doi.org/10.1002/esp.4715, 2019.

Giovagnoli, M. C.: Geoheritage in Italy, in Landscapes and Landforms of Italy, edited by: Soldati, M., and Marchetti, M., Springer International Publishing, Cham, 491-500, https://doi.org/10.1007/978-3-319-26194-2_42, 2017.

Gorbushina, A. A.: Life on the rocks, Environ. Microbiol., 9, 16131631, https://doi.org/10.1111/j.1462-2920.2007.01301.x, 2007.

Gordon, J. E. and Barron, H. F.: Scotland's Geodiversity: Development of the Basis for a National Framework, Scottish Natural Heritage Commissioned Report No. 417, available at: http://nora.nerc.ac.uk/id/eprint/19222/1/National_ 
Geodiversity_Framewrok_417.pdf (last access: 30 September 2021), 2011.

Gordon, J. E., Crofts, R., and Díaz-Martínez, E.: Geoheritage Conservation and Environmental Policies: Retrospect and Prospect, in: Geoheritage, edited by: Reynard, E. and Brilha, J., Elsevier, Amsterdam, 213-235, https://doi.org/10.1016/B978-0-12809531-7.00012-5, 2018a.

Gordon, J. E., Crofts, R., Díaz-Martínez, E., and Woo, K. S.: Enhancing the Role of Geoconservation in Protected Area Management and Nature Conservation, Geoheritage, 10, 191-203, https://doi.org/10.1007/s12371-017-0240-5, 2018b.

Grandgirard, V.: Géomorphologie et gestion du patrimoine naturel: la mémoire de la Terre est notre mémoire, Geogr. Helv., 52, $47-$ 56, https://doi.org/10.5194/gh-52-47-1997, 1997a.

Grandgirard, V.: Géomorphologie, protection de la nature et gestion du paysage, $\mathrm{PhD}$ Thesis in Geography, University of Fribourg, Fribourg, Switzerland, 1997b.

Gray, M.: Geodiversity: valuing and conserving abiotic nature, John Wiley \& Sons, Chichester, UK, 2004.

Gray, M.: Geodiversity and geoconservation: what, why, and how?, The George Wright Forum, 22, 4-12, 2005.

Gray, M.: Other nature: geodiversity and geosystem services, Environ. Conserv., 38, 271-274, https://doi.org/10.1017/S0376892911000117, 2011

Gray, M.: Geodiversity: valuing and conserving abiotic nature, 2nd Edc., John Wiley \& Sons, Chichester, UK, 2013.

Gray, M.: Geodiversity: The Backbone of Geoheritage and Geoconservation, in: Geoheritage, edited by: Reynard, E. and Brilha, J., Elsevier, Amsterdam, 13-25, https://doi.org/10.1016/B978-012-809531-7.00001-0, 2018.

Gray, M., Gordon, J. E., and Brown, E. J.: Geodiversity and the ecosystem approach: the contribution of geoscience in delivering integrated environmental management, P. Geologist. Assoc., 124, 659-673, https://doi.org/10.1016/j.pgeola.2013.01.003, 2013.

Guisan, A., Tingley, R., Baumgartner, J. B., Naujokaitis-Lewis, I., Sutcliffe, P. R., Tulloch, A. I. T., Regan, T. J., Brotons, L., McDonald-Madden, E., Mantyka-Pringle, C., Martin, T. G., Rhodes, J. R., Maggini, R., Setterfield, S. A., Elith, J., Schwartz, M. W., Wintle, B. A., Broennimann, O., Austin, M., Ferrier, S., Kearney, M. R., Possingham, H. P., and Buckley, Y. M.: Predicting species distributions for conservation decisions, Ecol. Lett., 16, 1424-1435, https://doi.org/10.1111/ele.12189, 2013.

Hjort, J. and Luoto, M.: Interaction of geomorphic and ecologic features across altitudinal zones in a subarctic landscape, Geomorphology, 112, 324-333, https://doi.org/10.1016/j.geomorph.2009.06.019, 2009.

Hjort, J., Gordon, J. E., Gray, M., and Hunter, M. L.: Why geodiversity matters in valuing nature's stage, Conserv. Biol., 29, 630-639, https://doi.org/10.1111/cobi.12510, 2015.

Howard, J. A. and Mitchell, C. W.: Phytogeomorphology, Wiley, New York, 1985.

IPCC: Global warming of $1.5^{\circ} \mathrm{C}$, in: An IPCC Special Report on the impacts of global warming of $1.5^{\circ} \mathrm{C}$ above pre-industrial levels and related global greenhouse gas emission pathways, in the context of strengthening the global response to the threat of climate change, sustainable development, and efforts to eradicate poverty, Geneva, Switzerland, 2018.

Klanderud, K. and Totland, Ø.: Habitat dependent nurse effects of the dwarf-shrub Dryas octopetala on alpine and arctic plant community structure, Écoscience, 11, 410-420, https://doi.org/10.1080/11956860.2004.11682850, 2004.

Knox, J. C.: Valley Alluviation in Southwestern Wisconsin, Ann. Assoc. Am. Geogr., 62, 401-410, https://doi.org/10.1111/j.14678306.1972.tb00872.x, 1972.

Körner, C.: Alpine plant life: functional plant ecology of high mountain ecosystems, 2nd Edn., Springer-Verlag, Berlin, Heidelberg, 2003.

Kubalíková, L.: Geomorphosite assessment for geotourism purposes, Czech J. Tourism, 2, 80-104, https://doi.org/10.2478/cjot2013-0005, 2013.

Lambiel, C., Bardou, E., Delaloye, R., Schoeneich, P., and Schütz, P.: Permafrost-Vaud. Etat des lieux de la distribution du pergélisol et du risque périglaciaire dans le canton de Vaud, Rapport d'étude, Université de Lausanne, Lausanne, Université de Fribourg, Fribourg, 2008.

Lane, S. N., Borgeaud, L., and Vittoz, P.: Emergent geomorphicvegetation interactions on a subalpine alluvial fan, Earth Surf. Proc. Land., 41, 72-86, https://doi.org/10.1002/esp.3833, 2016.

Larwood, J. G., Badman, T., and McKeever, P. J.: The progress and future of geoconservation at a global level, P. Geologist. Assoc., 124, 720-730, https://doi.org/10.1016/j.pgeola.2013.04.001, 2013.

Lawler, J. J., Ackerly, D. D., Albano, C. M., Anderson, M. G., Dobrowski, S. Z., Gill, J. L., Heller, N. E., Pressey, R. L., Sanderson, E. W., and Weiss, S. B.: The theory behind, and the challenges of, conserving nature's stage in a time of rapid change, Conserv. Biol., 29, 618-629, https://doi.org/10.1111/cobi.12505, 2015.

le Roux, P. C. and Luoto, M.: Earth surface processes drive the richness, composition and occurrence of plant species in an arctic-alpine environment, J. Veg. Sci., 25, 45-54, https://doi.org/10.1111/jvs.12059, 2014.

Martin, S.: Valoriser le géopatrimoine par la méditation indirecte et la visualisation des objets géomorphologiques (Géovisions no. 41), PhD thesis, Institut de géographie et durabilité, Université de Lausanne, Lausanne, 2013.

Masseroli, A., Leonelli, G., Bollati, I., Trombino, L., and Pelfini, M.: The influence of geomorphological processes on the treeline position in Upper Valtellina (Central Italian Alps), Geogr. Fis. Din, Quat., 39, 171-182, https://doi.org/10.4461/GFDQ.2016.39.16, 2016.

Masseroli, A., Bollati, I., Proverbio, S., Pelfini, M., and Trombino, L.: Soils as a useful tool for reconstructing geomorphic dynamics in high mountain environments: The case of the Buscagna stream hydrographic basin (Lepontine Alps), Geomorphology, 371, 107442, https://doi.org/10.1016/j.geomorph.2020.107442, 2020.

Matthews, J. A.: The ecology of recently-deglaciated terrain: a geoecological approach to glacier forelands, Cambridge University Press, Cambridge, 1992.

Mod, H. K., Scherrer, D., Luoto, M., and Guisan, A.: What we use is not what we know: environmental predictors in plant distribution models, J. Veg. Sci., 27, 1308-1322, https://doi.org/10.1111/jvs.12444, 2016.

Moreau, M., Mercier, D., Laffly, D., and Roussel, E.: Impacts of recent paraglacial dynamics on plant colonization: A case study on Midtre Lovénbreen foreland, Spitsbergen $\left(79^{\circ} \mathrm{N}\right)$, Geomorphology, 95, 48-60, https://doi.org/10.1016/j.geomorph.2006.07.031, 2008. 
Mucivuna, V. C., Reynard, E., and da Garcia, M. G. M.: Geomorphosites Assessment Methods: Comparative Analysis and Typology, Geoheritage, 11, 1799-1815, https://doi.org/10.1007/s12371-019-00394-x, 2019.

Osterkamp, W. R., Hupp, C. R., and Stoffel, M.: The interactions between vegetation and erosion: new directions for research at the interface of ecology and geomorphology, Earth Surf. Proc. Land., 37, 23-36, https://doi.org/10.1002/esp.2173, 2012.

Panizza, M.: Geomorphosites: Concepts, methods and examples of geomorphological survey, Chinese Sci. Bull., 46, 4-5, https://doi.org/10.1007/BF03187227, 2001.

Panizza, M. and Piacente, S.: Pour une géomorphologie culturelle, in: Paysages géomorphologiques, Actes du séminaire de troisième cycle de géographie Paysages géomorphologiques, organisé par les Instituts de Géographie des Universités de Lausanne et Fribourg du 10 au 14 février et du 25 au 29 août 2003, Lausanne, 194-210, 2004.

Pelfini, M. and Bollati, I.: Landforms and geomorphosites ongoing changes: concepts and implications for geoheritage promotion, Quaestiones Geographicae, 33, 131-143, https://doi.org/10.2478/quageo-2014-0009, 2014.

Pelfini, M. and Gobbi, M.: Enhancement of the ecological value of Forni Glacier (Central Alps) as a possible geomorphosite: New data from arthropod communities, Geogr. Fis. Din. Quat., 28, 211-217, 2005.

Pelfini, M., Garavaglia, V., and Bollati, I.: Dendrogeomorphological investigations for assessing ecological and educational value of glacial geomorphosites. Two examples from the Italian Alps, in: Mapping Geoheritage, edited by: Regolini-Bissig, G. and Reynard, E., Institut de géographie, Université de Lausanne, Lausanne, 81-95, 2010.

Pereira, P., Pereira, D., and Caetano Alves, M. I.: Geomorphosite assessment in Montesinho Natural Park (Portugal), Geogr. Helv., 62, 159-168, https://doi.org/10.5194/gh-62-159-2007, 2007.

Perret, A. and Martin, S.: Carte géomorphologique du vallon de Nant et étude de la marge proglaciaire du glacier des Martinets, Bulletin de la Murithienne, 132, 69-82, 2015.

Phillips, J. D. and Lorz, C.: Origins and implications of soil layering, Earth-Sci. Rev., 89, 144-155, https://doi.org/10.1016/j.earscirev.2008.04.003, 2008.

Picket, S. T. A. and White, P. S.: The ecology of natural disturbance and path dynamics, Academic Press, Orlando, Florida, 1985.

Portal, C.: Reliefs et patrimoine géomorphologique. Applications aux parcs naturels de la façade atlantique européenne, $\mathrm{PhD}$ Thesis, Université de Nantes, Nantes, 2010.

Pralong, J.-P.: A method for assessing tourist potential and use of geomorphological sites, Géomorphologie, 11, 189-196, https://doi.org/10.4000/geomorphologie.350, 2005.

Pralong, J.-P.: Géotourisme et utilisation de sites naturels d'intérêt pour les sciences de la Terre: les régions de Crans-MontanaSierre (Valais, Alpes suisses) et Chamonix-Mont-Blanc (HauteSavoie, Alpes françaises), PhD Thesis, Faculté des géosciences et de l'environnement, Université de Lausanne, Lausanne, 2006.

Prosser, C. D.: The history of geoconservation in England: legislative and policy milestones, Geol. Soc. Lond. Spec. Publ., 300, 113-122, https://doi.org/10.1144/SP300.9, 2008.

Reynard, E.: Géotopes, géo (morpho) sites et paysages géomorphologiques, in: Paysages géomorphologiques, Actes du séminaire de troisième cycle de géographie Paysages géomor- phologiques, organisé par les Instituts de Géographie des Universités de Lausanne et Fribourg du 10 au 14 février et du 25 au 29 août 2003, Lausanne, 123-136, 2004a.

Reynard, E.: La géomorphologie et la création des paysages, in: Paysages géomorphologiques, Actes du séminaire de troisième cycle de géographie Paysages géomorphologiques, organisé par les Instituts de Géographie des Universités de Lausanne et Fribourg du 10 au 14 février et du 25 au 29 août 2003, Lausanne, 9-20, 2004b.

Reynard, E.: Protecting Stones: Conservation of Erratic Blocks in Switzerland, in: Dimension Stone 2004. New perspectives for a traditional building material, edited by: Přikryl, R., Balkema, Leiden, 3-7, 2004c.

Reynard, E.: Géomorphosites et paysages, Géomorphologie, 11, 181-188, https://doi.org/10.4000/geomorphologie.338, 2005.

Reynard, E.: Geomorphosites: definitions and characteristics, in: Geomorphosites, edited by: Reynard E., Coratza, P., and Regolini-Bissig, G., Pfeil, München, 9-20, 2009.

Reynard, E. and Coratza, P.: Scientific research on geomorphosites. A review of the activities of the IAG working group on geomorphosites over the last twelve years, Geogr. Fis. Din. Quat., 36, 159-168, https://doi.org/10.4461/GFDQ.2013.36.13, 2013.

Reynard, E. and Panizza, M.: Géomorphosites: définition, évaluation et cartographie. Une introduction, Géomorphologie, 11, 177-180, 2005.

Reynard, E., Pralong, J.-P., and Gentizon, C.: La géoconservation: pour un renouvellement de la protection de la nature en Suisse, in: Vivre dans les milieux fragiles: Alpes et Sahel, edited by: Dambo, L. and Reynard, E., Institut de Géographie, Lausanne, 57-70, 2005.

Reynard, E., Fontana, G., Kozlik, L., and Scapozza, C.: A method for assessing "scientific" and "additional values" of geomorphosites, Geogr. Helv., 62, 148-158, https://doi.org/10.5194/gh62-148-2007, 2007.

Reynard, E., Hobléa, F., Cayla, N., and Gauchon, C.: Les hauts lieux géologiques et géomorphologiques alpins. Vers une redécouverte patrimoniale?, Rev. Géogr. Alp., 99, 2, https://doi.org/10.4000/rga.1412, 2011.

Reynard, E., Perret, A., Bussard, J., Grangier, L., and Martin, S.: Integrated Approach for the Inventory and Management of Geomorphological Heritage at the Regional Scale, Geoheritage, 8, 43-60, https://doi.org/10.1007/s12371-015-0153-0, 2016.

Reynard, E., Buckingham, T., Martin, S., and Regolini, G.: Geoheritage, Geoconservation and Geotourism in Switzerland, in Landscapes and Landforms of Switzerland, edited by: Reynard, E., Springer International Publishing, Cham, 411-425, https://doi.org/10.1007/978-3-030-43203-4_29, 2021.

Rice, S., Stoffel, M., Turowski, J. M., and Wolf, A.: Disturbance regimes at the interface of geomorphology and ecology, Earth Surf. Proc. Land., 37, 1678-1682, https://doi.org/10.1002/esp.3326, 2012.

Scherrer, D. and Körner, C.: Topographically controlled thermalhabitat differentiation buffers alpine plant diversity against climate warming, J. Biogeogr., 38, 406-416, 2011.

Sharples, C.: Concepts and principles of geoconservation, Tasmanian Parks \& Wildlife Service, Hobart, 2002.

Stallins, A. J. and Corenblit, D.: Interdependence of geomorphic and ecologic resilience properties in a 
geographic context, Geomorphology, 305, 76-93, https://doi.org/10.1016/j.geomorph.2017.09.012, 2018.

Stallins, J. A.: Geomorphology and ecology: Unifying themes for complex systems in biogeomorphology, Geomorphology, 77, 207-216, https://doi.org/10.1016/j.geomorph.2006.01.005, 2006.

Steinbauer, M. J., Grytnes, J.-A., Jurasinski, G., Kulonen, A., Lenoir, J., Pauli, H., Rixen, C., Winkler, M., Bardy-Durchhalter, M., Barni, E., Bjorkman, A. D., Breiner, F. T., Burg, S., Czortek, P., Dawes, M. A., Delimat, A., Dullinger, S., Erschbamer, B., Felde, V. A., Fernández-Arberas, O., Fossheim, K. F., GómezGarcía, D., Georges, D., Grindrud, E. T., Haider, S., Haugum, S. V, Henriksen, H., Herreros, M. J., Jaroszewicz, B., Jaroszynska, F., Kanka, R., Kapfer, J., Klanderud, K., Kühn, I., Lamprecht, A., Matteodo, M., di Cella, U. M., Normand, S., Odland, A., Olsen, S. L., Palacio, S., Petey, M., Piscová, V., Sedlakova, B., Steinbauer, K., Stöckli, V., Svenning, J.-C., Teppa, G., Theurillat, J.-P., Vittoz, P., Woodin, S. J., Zimmermann, N. E., and Wipf, S.: Accelerated increase in plant species richness on mountain summits is linked to warming, Nature, 556, 231234, https://doi.org/10.1038/s41586-018-0005-6, 2018.

Stöckli, V., Wipf, S., Nilsson, C., and Rixen, C.: Using historical plant surveys to track biodiversity on mountain summits, Plant Ecol. Divers., 4, 415-425, 2011.

Strasser, A., Heitzmann, P., Jordan, P., Stapfer, A., Stürm, B., Vogel, A., and Weidmann, M.: Géotopes et la protection des objets géologiques en Suisse: un rapport stratégique, Groupe de travail suisse pour la protection des géotopes, Fribourg, 1995.

Štrba, L., Rybár, P., Baláž, B., Molokáč, M., Hvizdák, L., Kršák, B., Lukáč, M., Muchová, L., Tometzová, D., and Ferenčíková, J.: Geosite assessments: comparison of methods and results, Curr. Issues. Tour., 18, 496-510, https://doi.org/10.1080/13683500.2014.882885, 2015.
Viles, H.: Biogeomorphology, in: Encyclopedia of geomorphology, edited by: Goudie, A., Routledge, London, 83-86, 2004.

Viles, H.: Biogeomorphology: Past, present and future, Geomorphology, 366, 106809, https://doi.org/10.1016/j.geomorph.2019.06.022, 2019.

Virtanen, R., Luoto, M., Rämä, T., Mikkola, K., Hjort, J., Grytnes, J.-A., and Birks, H. J. B.: Recent vegetation changes at the highlatitude tree line ecotone are controlled by geomorphological disturbance, productivity and diversity, Global Ecol. Biogeogr., 19, 810-821, https://doi.org/10.1111/j.1466-8238.2010.00570.x, 2010.

Wilkinson, M. T., Richards, P. J., and Humphreys, G. S.: Breaking ground: Pedological, geological, and ecological implications of soil bioturbation, Earth-Sci. Rev., 97, 257-272, https://doi.org/10.1016/j.earscirev.2009.09.005, 2009.

Wipf, S., Stöckli, V., Herz, K., and Rixen, C.: The oldest monitoring site of the Alps revisited: accelerated increase in plant species richness on Piz Linard summit since 1835, Plant Ecol. Divers., 6, 447-455, https://doi.org/10.1080/17550874.2013.764943, 2013.

Zheng, F.-L.: Effect of Vegetation Changes on Soil Erosion on the Loess Plateau, Pedosphere, 16, 420-427, https://doi.org/10.1016/S1002-0160(06)60071-4, 2006.

Zouros, N. C.: Geomorphosite assessment and management in protected areas of Greece Case study of the Lesvos island - coastal geomorphosites, Geogr. Helv., 62, 169-180, https://doi.org/10.5194/gh-62-169-2007, 2007. 